\title{
The Historical Evolution of International Humanitarian Law (IHL) from Earliest Societies to Modern Age
}

\author{
Mohammad Saidul Islam \\ Department of Law International Islamic University, Chittagong, Bangladesh \\ Email: islamm.saidul@yahoo.com
}

How to cite this paper: Islam, M. S. (2018). The Historical Evolution of International Humanitarian Law (IHL) from Earliest Societies to Modern Age. Beijing Law Review, 9, 294-307. https://doi.org/10.4236/blr.2018.92019

Received: Apr. 22, 2018

Accepted: June 18, 2018

Published: June 21, 2018

Copyright $\odot 2018$ by author and Scientific Research Publishing Inc. This work is licensed under the Creative Commons Attribution International License (CC BY 4.0).

http://creativecommons.org/licenses/by/4.0/

Open Access

\begin{abstract}
International humanitarian law earlier known as the law of war is applied in the armed conflict to protect those who don 't take part in the hostilities or no longer taking part in the hostilities. Even in absence of any international document the earliest societies or communities would have followed some rules of war during conflict either as per the instructions of the community leader or customs or religions. The paper addresses the earlier scattered provisions of the law of war (LOW) or international humanitarian law (IHL) in various religious books, customs and practices. It then turns to the development of IHL by the codification of the rules of war in various international and national documents. This article also focuses on the significant development of IHL by adopting the four Geneva conventions (GCs) and its three additional protocols (AP) and most importantly progress and promotion of IHL by incorporating the laws of armed conflict in the national legislations.
\end{abstract}

\section{Keywords}

Development, IHL, Evolution, Geneva, National Legislation

\section{Introduction}

The rules of conflict or fight, although, first documented in 1863 after the war of Solferino, it was slightly existed and practiced from the beginning of human being. The earliest societies, the Papua, the Sumerians, Babylon, Persians, the Greek, and the Roman, in all societies had some rules of fighting and these rules were strictly followed by people. Every religion namely, Islam, Christian, Jesus, Hindu and Buddhist contains a handful of provisions on the law of armed con- 
flict (LOAC). The scattered provisions of LOAC have been accumulated in the documents, the Lieber Code in 1863 and the first Geneva Convention in 1864. Later on many Conventions, Protocols, Declarations on Armed Conflicts (AC) have been adopted in various time depending on the nature of conflict and protection of the victims. Four Geneva Conventions in 1949, its three APs in 1977 and 2005 and the permanent International Criminal Court in 1998 have given a great success to the development of IHL. This article explores the evolution of IHL from the earliest societies to the modern age.

\section{International Humanitarian Law in the Earliest Societies}

The history of IHL is not a new one. The laws of war are as old as war itself and war is as old as life on earth. Even the modern naturalists have identified that some rules are being practiced by animals also during the time of their combat. For example, when the deer fights with other types of deer or two wolves or dogs fight, the one who knows that he is losing, he gives up the fighting or some time offers surrender by exposing his throat to the victor, who as a result abstains to bite him.

In the earliest societies, the victory was followed by massive massacre or unspeakable atrocities where the code of honor had completely prohibited surrendering and the worriers had to win or die. Even in that period also, the wounded soldiers were collected and cared for (Pictet, 1984).

The study of savage tribes existing in our own time gives some insight into the nature of primitive people at the dawn of society. In Papua, where such tribes would have maintained some rules such as warning in advance to the enemies, non-engaging into the war until both the parties are ready and suspending war for 15 days in case of death or serious injury of any soldier (Pictet, 1984: pp. 6-7).

The Sumerians treated war as a state governed by the law and it was started by a declaration of war and terminated by a peace treaty. The Code of Hammurabi by Hammurabi king of Babylon, (1728-1686 BC) ensured the protection of the weak from the oppressive hands of the rich and strong and made the provision of release of the hostages by ransom.

In the 7th century BC, King of the Persians, Cyrus I, ordered that the wounded soldiers would be treated and cared for like the own wounded soldiers. The killing of a surrendered adversary was absolutely prohibited to kill under the Indian epic Mahabharata (c. 400BC) and the Laws of Manu as they were unable to fight. It also forbade using certain weapons such as poisoned or burning arrows and ensured the protection of enemy property and the status of the prisoners of war (Fleck \& Bothe, 1999: p. 16).

The Greeks considered each one should have equal rights in the wars between the Greek city-states and in the war led by Alexander the Great who led the war against the Persians ensured respect for the life and personal dignity of war victims. The Romans also accorded the right to life to their prisoners of war (Gill \& Fleck, p. 16). 
Although the earliest societies are considered as the uncivilized nations yet they have some principles for conducting the war against their own society or others and they would have strictly complied with those rules. The existence of law of war can be found in the ancient period, for example, the Papuan tribal groups, the Persians, the Sumerian, the Greeks, the Romans and so on, have their own customs of conducting war not like modern international humanitarian law.

\section{International Humanitarian Law in Islam}

In the Holy Quran and Hadith many provisions of modern IHL have elaborately been discussed and these rules were practiced by the Muslims in many wars. For the protection of the non-combatant, Allah (1: 190) declares; "Fight in the name of Allah those who fight you and do not transgress limits: for Allah does not love transgressors." This verse highlighted two important aspects of the law of war; firstly, the fighting must be only against those who fight against the Muslims and Muslims should not initiate hostilities. Secondly, those who are not participating in the war are protected (Khan, 2013).

This provision is equal to the principle of distinction which is one of the basic principles of the IHL. In modern IHL the parties of the armed conflict are to maintain some principles which are the principle of distinction, the principle of precaution, the principle of proportionality and the principle of limitation. The existence of these principles can be found in Islamic law especially in the speech of Hazrat Muhammad (sm) who states that never, never kill a woman and a servant. $^{2}$ The Prophet (pbuh) also prohibited the killing of any old aged and weak person or any children or any women. ${ }^{3}$ After conquering Makka the Prophet (sm) did not do any harm to any person or property and announced that all captured, wounded and home shelter taking people were protected. ${ }^{4}$ Abu Bakar (R) instructed his army as follows when he sent them to Syria headed by Yazid $b$. Abu Sufyan (d.18/693) which are; 1) do not embezzle, 2) do not cheat, 3) do not breach trust, 4) do not mutilate the dead, 5) do not slay the elderly, women, and children, 6) do not inundate a date-palm nor burn it, 7) do not cut down a fruit tree, 8) do not kill cattle unless they were needed for food, 9) don't destroy any building, 10) May be, you will pass by people who have secluded themselves in convents; leave them and do not interfere in what they do."

Almost every important aspect of modern IHL namely protection of the civilians, their property and the prisoner of war, has been dealt with by Islamic law more than 14 hundred years ago and was absolutely practiced by the Hazrat ${ }^{1}$ Sura Bakarah, verse; 190.

${ }^{2}$ See (Kitab al-Siyar al-Kabir, 4:186, Abdur Razzaq, Musannaf, hadith no. 9382, Al-Tabrizi, Mishkat al-masabih, hadith no. 3955; Ibn Majah, Sunnan, 2: hadith no. 2842; Al-Nasai, al-Sunnan al-Kubra, 2: hadith no. 8625 and 8626; Imam Baihaqi, Ma'rifat al-Sunnan, hadith no. 5643; Al-Baihaqi, Sunnan, 9:83, kitab al-siyar.

${ }^{3}$ Abu Dawud, Sunnan, 2:44, hadith no. 2613.

${ }^{4}$ Baihaqi, Sunan, 8:181, hadith no. 16524; Abdur Razzaq, Musannaf, 10:123. hadith no. 18590.

${ }^{5}$ Bayhaqi, Sunnan, 9:85, ; Shoukani, Nayl al-Awtar, 7: 249. 
Muhammad (Sm) and his companions during AC.

\section{Documentation of Rules Relating to Wars}

The aforesaid discussion shows the efforts to regulate warfare existed to a greater or lesser extent from the very ancient period. Those initiatives were not sufficient to regulate the conducts of parties during warfare until these rules had been documented in any instrument. Regarding documentation of the laws of war first initiative was taken in 1864 following the proposal of Henry Dunant in his book "A Memory of Solferino". Dunant wrote this book witnessing a bloody war between French and Austrian Armies in 1863 where about 38,000 people were killed or wounded in 15 hours. In this devastating war, doctor or nurse or medical or auxiliary personnel or stretcher bearer none was beyond the attack of enemy (Draper, 1979: p. 9). Dunant, in the book "A Memory of Solferino" described his experiences what he witnessed in the battle of solferino and simultaneously in his book he made two proposals firstly, "each state should establish in time of peace a relief society to aid the army medical services in time of war" and secondly, "state should conclude a treaty that would facilitate the activities of these relief societies and guarantee a better treatment of the wounded". In next year the International Committee for the Relief of Military Wounded was established with its permanent seat in Geneva. The great success of the committee was that, within a very short time, it succeeded to persuade the Swiss government to convene an international conference (Sassòli et al., 2012).

The Swiss Government convened the conference in August 1864 and adopted the "Geneva Convention for the Amelioration of the Condition of the Wounded in Armies in the Field in 1864". Prior to adopting this international document, an attempt was taken in 1863 to gather laws and customs of war by Francis Lieber in his valuable document "The Lieber Code" promulgated as General Orders No. 100 by President Lincoln. The Code (1863) provides detailed rules on the entire range of warfare.

In 1868 , the St. Petersburg Declaration was adopted and it was stated that only the legitimate object which the State shall endeavor to do during the war is to weaken the military forces of the enemy so the target would be only the combatants and combatants only. To achieve this objective it is sufficient to disable the greatest possible number of combatants. It has also been stated that this object would be exceeded by the employment of arms which uselessly aggravate the sufferings of disabled men, or render their death inevitable. To this end, the declaration outlawed certain fragmenting, explosive and incendiary ammunition (Declaration Renouncing the Use, in Time of War, of Certain Explosive Projectiles Saint Petersburg, 1868).

On the initiative of Czar Alexander II of Russia, the delegates of the 15 countries met in Brussels on $27^{\text {th }}$ July, 1874 intending to examine the draft submitted by the Russian Government for consideration regarding codification of the LOW. The conference adopted the draft titled "The Brussels Declaration" with 
some minor changes but it was not ratified due to unwillingness of most of the countries regarding binding effects of the document.

Subsequently, at the initiative of Russian citizen Tsar Nicholas II, the world community convened two conferences at Hague, Netherlands, in 1899 and 1907 respectively. Both the conferences discussed on disarmament, laws of war and war crime and banned some other weapons and methods of war including "Dum Dum" bullets, (which expand in the body), poison weapons, and attacks from hot air balloons and it set out rules for the humane treatment of prisoners of war, occupied territory, and neutral parties. The first conference opened on 18 May, 1899 and signed six important documents on 9 July, 1899 (came into force in 1900).

On the suggestion of US President Theodore Roosevelt, in 1904, the European community initiated to convene the second Hague conference but it did not happen due to war between Russia and Japan and later on it was held from 15 June to 18 October 1907. The conference intended to modify and enlarge the conventions adopted in 1899 and simultaneously initiated to add some new provisions especially on naval warfare but it could not be done due to the strong opposition of Germany, yet some important 14 conventions and regulations have been signed.

A third conference was planned to be held in 1914 and rescheduled for 1915 was not held due to the First World War on 28 July, 1914. In the First World War, the provisions of the Hague Conventions had apparently been violated by the parties of the war. During the World War I, it became vivid that there were huge deficiencies and lack of precision in the Hague Regulations of 1899 and 1907. Instantly during the subsistence of the war some special agreements were made between belligerents in Berne in 1917 and 1918 and after the end of First World War, the world community, observing the devastating and horrified scenario, was much concerned to save the world from any further war and to this end they established the League of Nations under the treaty of Versailles 1919 with the objectives to promote international co-operation and to achieve international peace and security (Preamble, The Covenant of the League of Nations, 1919).

Later on, under the auspices of the League of Nations, a conference was held in Geneva from 4 May to 17 June 1925. In this conference two documents were signed: (i) "the Convention for the Supervision of the International Trade in Arms, Munitions and Implements of War which has not entered into force, and (ii) the Protocol for the Prohibition of the Use of Asphyxiating, Poisonous or Other Gases, and of Bacteriological Methods of Warfare." ICRC started to re-think the treatment of prisoner of war that led to the preparation of another international treaty further defining the status of prisoners of war. In 1921 in the International Red Cross Conference in Geneva, they expressed a wish for the formation of a special convention for the treatment of prisoners of war and subsequently adopted a draft convention on the treatment of prisoners of war. That 
draft Convention was submitted to the Diplomatic Conference held in 1929 in Geneva where the "Convention Relative to the Treatment of Prisoners of War 1929" was adopted and entered into effect on June 19, 1931.

After several years the most horrified war of the world history was observed by the world for about six years from 1939 to 1945 known as the Second World War. It is estimated that about 50 million to 85 million fatalities resulted in this deadliest AC in human history (James, 2009: p. 49). About 40 million civilians lost their lives in this dangerous war. This massive deportation and murder of the civilians as well as taking and killing hostages drew the international attention on the protection of civilians.

\section{Geneva Conventions and Development of IHL}

During the war, ICRC was largely engaged in activities in the war field such as supplying food to the civilians, wounded and other victims, collecting the wounded from the armed field etc and simultaneously it continued to discuss with the world communities regarding the possibility of re-launching the process of revising and extending the law of Geneva as soon as possible. To this end, before the end of hostilities in February 1945, ICRC expressed its intention to adopt new conventions revising the existing GCs and accordingly they communicated it to the government. At the initiative of ICRC in September 1945 a preliminary conference of National Red Cross Societies was organized in Geneva, followed by a Conference of Government Experts in 1947 (Spoerri, 2009). The submitted draft revision of the GCs by ICRC mainly highlighted the following objectives; 1) extension of the protection of the civilians 2) ensuring the protection of the civil wars victims, 3) improving the enforcement mechanisms of the conventions, and 4) enhancing the scope of application of the conventions in all ACs (ICRC, 2005).

This proposal of revising the conventions received rapid positive response from many corner of the globe. It has already been supported by the government experts, gathered in 1947 and the participants of the 17th International Conference of the Red Cross in Stockholm in 1948. ICRC, after obtaining support from the various governments, invoked the Swiss government to convene a diplomatic conference. The Swiss government called a conference and it was held from 21 April to 12 August 1949 where representatives from 64 countries participated, covering almost every State in the world at that time. In this conference four GCs (Geneva Convention I, II, II, and IV) had been adopted and signed on 12 August 1949 and that was the date on which the Final Act of the diplomatic conference was signed. Three out of these four conventions which are relative to wounded and sick and shipwrecked members of the armed forces and prisoners of war which were existing prior to adopting these Conventions in 1949, in this conference those had been reviewed, modified and improved and the fourth one which was almost entirely new, related to the protection of the civilians, had filled the gaps felt keenly by the world community during the Second World 
War (Claude et al., 1987).

These conventions prescribe some rules regarding protection of the combatants or the members of the armed forces, who are wounded, sick or shipwrecked, prisoners of war and most importantly the civilians including medical personnel, religious military personnel, military chaplains and civilian support workers of the military. The GCs have achieved a huge success from the very beginning of signing these documents, it became effective within less than one year from the date of signing, on 21 October 1950 after first two ratifications and interestingly 74 states had ratified in that year. Now the GCs have become universal documents as all the states of the world have ratified these documents.

\section{Ratifications of the Geneva Conventions}

\begin{tabular}{ccc}
\hline Conventions/Protocols & Signatory & Bangladesh ratified \\
\hline "First Geneva Conventions of 12 August, 1949" & 196 countries & 1972 \\
"Second Geneva Conventions of 12 August, 1949" & 196 countries & 1972 \\
"Third Geneva Conventions of 12 August, 1949" & 196 countries & 1972 \\
"Fourth Geneva Conventions of 12 August, 1949" & 196 countries & 1972 \\
\hline
\end{tabular}

As early as in 1950s ICRC identified some new developments of means of warfare, i.e., landmine, atomic, chemical and bacteriological weapons, which had not been covered by the GCs (Maresca \& Maslen, 2000). The ICRC was extremely concerned for the development of these new weapons. The Board of Governors, therefore, in 1954, asked ICRC to propose a text to the next "International Conference of the Red Cross" with a view to protecting the civilians from the dangers of the newly developed weapons. Accordingly, ICRC prepared the draft rules named "Draft Rules for the Limitation of the Dangers Incurred by the Civilian Population in Time of War" with the help of experts. But it did not come into effect ("Draft Rules" ICRC, 1956). This "Draft Rules for the Limitation of the Dangers Incurred by the Civilian Population in Time of War" was published in 1956 and has become an important document of IHL for the protection of civilians from the dangers of landmines, atomic, chemical and bacteriological warfare (Terry \& Dieter, 2010: p. 16).

\section{The Additional Protocols of Geneva Conventions and Promotion of IHL}

Subsequently, the $20^{\text {th }}$ International Conference of the Red Cross in 1965 laid down its four principles for the protection of the civilian population against the dangers of indiscriminate warfare and simultaneously urged the ICRC to pursue the development of IHL. Being encouraged both by International Conference of the Red Cross and United Nations Conference on Human Rights 1968 the ICRC submitted its plans to the "National Societies of the Red Cross and the Red Crescent" who were present at Geneva Conference. In its plans it had no inten- 
tion to rewrite or revise the existing GCs but it intended to reaffirm and develop the GCs by adopting some supplementary matters and clarifying some important points and similarly the idea of adopting the protocols additional to the GCs was soon conceived, and later on approved by the Governments.

In " $21^{\text {st }}$ International Conference of the Red Cross in 1969 in Istanbul" ICRC submitted an important report on this subject and unanimously a resolution was passed urging ICRC to take immediate effective steps for proposing a concrete rules as supplement to existing IHL. In order to carry out this task, ICRC convened the "Conference of Government Experts on the Reaffirmation and Development of International Humanitarian Law Applicable in Armed Conflicts" which was held from 24 May to 12 June 1971 where 200 members from 40 countries participated with a view to elaborate discussion on this subject. All the discussions had reduced to writing in 8 volumes numbering 800 pages. Within a short time after the conference of Government experts in November 1971, the ICRC gathered the opinions of various nongovernmental organizations and in March 1972, it once again consulted with the National Societies, which had been cordially invited to gather in Vienna by the Austrian Red Cross where ICRC submitted the first draft texts to them (Sandoz et al., 1987: p. xxxi).

The most significant session (the $2^{\text {nd }}$ session) of the Government experts was held from 3 May to 3 June 1972 in Geneva under the auspicious of ICRC where 400 experts from 77 countries participated and this extensive participation was divided into several committees to discuss the matter in conducive atmosphere and it led to the greatest development of IHL in the history. Following these sessions the ICRC drew up the complete text of two draft Protocols additional to the GCs, one for cases of international armed conflict, the other for non international armed conflicts.

In June the drafts protocols, its commentary and a report of the Conference were sent to all governments and these draft protocols were presented at the $22^{\text {nd }}$ ICRC conference the resolution no. XIII welcomed and recommended that governments should take steps to make the texts applicable globally. Thus these important documents on IHL were passed out of hands of ICRC where it intentionally avoided inserting any provisions on prohibiting or limiting conventional weapons (Sandoz et al., 1987: p. xxxii).

Later on, at the request of a group of experts, the question of conventional weapons was considered and with these aims two other sessions of a Conference of Government Experts were convened, in Lucerne in 1974 and in Lugarno in 1976. Finally the Swiss Government convened and organized "the Diplomatic Conference on the Reaffirmation and Development of International Humanitarian Law Applicable in Armed Conflicts in 1974" and continued from 1974 to 1977. The Conference was held in Geneva at the International Conference Centre and the representatives met in four important sessions. The first session was during 20 February to 29 March 1974 whereas the second session was started after almost one year 3 February 1975 continued till 18 April 1975, the third one 
was in the next year during 21 April to 11 June 1976 and the last session was from 17 March to 10 June 1977. In this historic conference 155 states varying from 107 to 124 in different sessions, 11 national liberation movements and 51 intergovernmental or non-governmental organizations and around 700 delegates participated and under the rules of procedure ICRC participated (Sandoz et al., 1987: p. xxxiii).

The Conference was sub-divided into three main plenary committees, the ad hoc committee on "conventional weapons", the Credentials Committee, the Drafting Committee, as well as numerous working groups. After threadbare discussions from different parts of the world from different angles the Protocols were adopted on 8 June 19 77, and the Diplomatic Conference ended two days later with the formal signature of the Final Act. Almost all delegations signed this. In the Annex of the Final Act, the texts of the two Protocols Additional to the GCs of 12 August 1949 have been included, representing the result of the conference. Following the ratification deposited by Ghana, and the accession by Libya, these instruments, which are of such fundamental importance for humanity, entered into force on 7 December 1978 (Sandoz et al., 1987: p. xxxiii).

The APs 1977 of GCs 1949 are surely a great achievement in the history of development of IHL, comparable to the revisions achieved in 1949 when four GCs have been adopted consisting of 600 articles of which almost 150 are new. Amongst the results achieved by the protocols, the most important one was the protection of the civilians against the dangers of hostilities. The Diplomatic Conference was mainly convened for reaffirmation and development of the norms relating to the protection of the civilians which had been fully neglected before the Fourth GC of 1949 and ensured protection for the civilian population (Arts. 48 and 51, AP1), civilian medical and religious personnel (Art. 15, AP1), Medical units (Art. 12, AP1), civilian objects (Art. 52, AP1) and object indispensible for the survival of the civilian population (Art. 54, AP1).

A major area is constituted by the complex subjects of war of liberations and guerrilla fighters which is considered a great innovation in the field of IHL. Another praiseworthy chapter of the protocol I, is the means and methods of warfare which were dealt in the Hague law in 1907 and there was a great need of upgrading these provisions. By inserting the norms of means and methods of warfare, both Geneva and Hague laws have been intertwined in a single document. The provision for the protection of environment during the $\mathrm{AC}$ is also a significant development (Arts. 35 and 55, AP1).

Finally, the provision regarding appointment of protecting power for the supervision and implementation of the conventions and of these protocols has increased the significance of the protocol enormously (Art. 5, AP1). The most significant development of IHL is the article 3 common to the GCs and AP II concerning application of IHL for the protection of the victims of non-international armed conflict (Common Article 3, GCs). Common article 3 is the keystone of humanitarian law applicable in non-international armed conflict and AP II has 
been adopted to amplify article 3 without changing the conditions of its application. Although common article 3 lays down the principles of protection of the victims of internal ACs, yet it was realized that another international document is essential for the protection from the hostilities of internal ACs, an unaddressed very common problem of the world, due to insufficiency of article 3 and non including some important matters in this norm.

The common article 3 prescribes the fundamental principles of protection but difficulties of application have emerged in practice. Sometime this brief set of rules has been proved as inadequate to deal properly the urgent humanitarian needs (Common article 3, GCs). Concerned with the need to fulfill the lacking of common article 3, the ICRC deemed it necessary to adopt another document inserting these matters as supplements and development of the common article 3 of the GCs 1949 and adopted "the APs to the Geneva Conventions of 12 August 1949, relating to the Protection of Victims of Non-International Armed Conflicts (Additional Protocol II)".

Following the tremendous development of IHL by the adoption of two APs in the 1970s, the past few decades proceeded forward without any interruption by adopting one after another document, for example, "1980 Convention on Prohibition or Restrictions on the Use of Certain Conventional Weapons, which May be Deemed to be Excessively Injurious or to Have Indiscriminate Effects (CCW), Protocol on Prohibition or Restrictions on the Use of Mines, Booby-Traps and Other Devices, 1980 Convention on the Prohibition of the Development, Production, Stockpiling and Use of Chemical Weapons and on their Destruction, 1993, International Tribunal for the Prosecution of Persons Responsible for Serious Violations of IHL Committed in the Territory of the Former Yugoslavia, 1994, Statute of the International Criminal Tribunal for Rwanda, 1994, Ottawa Treaty, 1997, Statute of the International Criminal Court, 1998, 2005 Protocol Additional to the Geneva Conventions of 12 August 1949, and Relating to the Adoption of an Additional Distinctive Emblem (Additional Protocol III) 2013 The Arms Trade Treaty".

The above shows that a lot of international conventions, declarations, protocols and treaties on IHL have been accepted from 1863 to date in terms of protecting the victims of AC. The people will get the benefit of this enriched law if the High Contracting Parties enact national legislation inserting the provision of the GCs, but, in this respect, the present situation is not fully satisfactory.

\section{National Legislations Contributing to the Development of IHL}

The domestic laws and international laws are not same especially in respect of implementation. National laws can easily be implemented by the state mechanisms but international law faces many obstacles in implementation for example, lack of interest of the State to ratify international documents or ratifying it with reservations, political prejudice, disagreement of the States on many matters, no 
executing authority, powerful State domination, proliferation of mass destructing weapons and so on. In international level, although, a lot of conventions and protocols have been adopted but implementation mechanisms are so weak due to reality, for this reasons; many scholars of international law don't agree to recognize international law as a law and described it as a weapons in the hands of powerful states. So an international law is called to have reached its apex development if that law is enacted in the state legislations by most of member states.

Although many countries have not enacted national legislations incorporating the provisions of GCs and APs, yet, it is worthy of mentioning here that the recent trend of the states is to enact national laws incorporating the provisions of GCs and its APs, i.e., "the Geneva Convention Act 1957 (Britain)", "the Geneva Convention Act 1963 (Ireland)", "International Crimes (Tribunal) Act 1973 (Bangladesh)", "Chemical Weapons (Prohibition) Act 2006 (Bangladesh)", "Geneva Convention Act 1969 (India)", "Chemical Weapons Act, 1993 (Pakistan)", "Chemical Weapons Act 2007 (Sri Lanka)", "the Geneva Convention Act 2012 (Sierra Leone)", "the US War Crimes Act 1996 (US)", "Cluster Munitions (Prohibitions) Act 2010 (UK)”, etc., for the implementation and enforcement of IHL which is considered as the vital development of IHL.

Many countries have already established separate tribunals for the trial of the perpetrators of war crimes. For example, Bangladesh and Sierra Leone have established separate courts for the trial of perpetrators of war crimes. Some other countries by legislation authorized the existing court to try and punish the perpetrators of war crimes or crime against humanity or genocide, for example, Bosnia and Herzegovina, Colombo.

In Bangladesh the International Crimes Tribunal Act 1973 (as amended in 2009) provides the provision of appeal which was absent in the Nuremberg Tribunal but both the provisions of appeal (Rome Statute of International Criminal Court, 1998) and revision (art. 84, Rome Statute 1998) have been inserted in the Rome Statue of the International Criminal Court. This tribunal has jurisdiction to try and punish any individual who commits or has committed crimes against humanity, crimes against peace, genocide, war crimes and so on in the territory of Bangladesh (Sec. 3, International Crimes Tribunal Act, 1973).

The Appellate Division Panel of the court of Bosnia and Herzegovina in an appeal presented by the defence of Mr. Ante Kovc, the court accepted the appeal and ordered a trial be carried out before the Appellate Panel of section I for war crimes. The Court after hearing the defence, Mr. Kovac was found guilty for having ordered and approved the illegal capture and detention in inhumane conditions of more than 250 Bosnian civilians in Vitez in 1993 and sentenced to thirteen years imprisonment (National Implementation of International $\mathrm{Hu}$ manitarian Law, 2010).

All of these national and international legislations and judgments by tribunals indicate the continuous development of the humanitarian law considering the changing characters of the means and methods of warfare but till now it did not 
reach to the satisfactory level. As in every day there is news of armed attacks and mostly the armed conflict not of an international character. It is the common practice of the States that they are interested to address the non-international armed conflict as internal problem where IHL cannot be applied. The Geneva Conventions have been signed by all countries of the world but the AP I and II have not been signed by many countries and even the Rome Statute has not been ratified by many States namely USA, Israel, Myanmar. On the other hand terrorism is now the big concern but the world communities could not come to a comprehensive definition of it and it also remains in the vague realm whether IHL applies in the terrorism and counter terrorism.

In international arena force cannot bear a good result for world peace, so the United Nations and other influential international organization need to play key role to pursue the States to sign and ratify the core documents of IHL. On the other hand the world communities should come to a consensus regarding some important issues, i.e., terrorism, counter-terrorism, cyber warfare, autonomous weapons and so on. Most importantly the signing states also need to take some measures during peace, conflict and post conflict time, namely making national legislation inserting the provision of IHL, disseminating the conventions and protocols to the people, appointing the advisor in the armed forces, settling safety zone, demilitarized zone, military area, translating the conventions and protocols into mother language, establishing court and tribunal, repatriating the arrested persons after conflict and so on.

\section{Conclusion}

Only less than a century ago the IHL was quite unknown to the general public and it was confined within the round table discussion and some documents but now it has become a popular branch of international law which has been accepted by all countries of the world and many countries following the obligations of the GCs made national legislations. The IHL previously known as LOW was limitedly in practice among the uncivilized societies also. The modern IHL is very strongly found in many religious books especially in the Holy Quran and the Hadith which significantly contributed towards the development of IHL.

Formally the journey of documentation of IHL started from the adopting of the GC of 1864. Since then many conventions, regulations and declarations on the laws of AC have been adopted and enacted both nationally and internationally till 1948. But the most significant documents of IHL were adopted in 1949 and 1977 by adopting GCs and its APs respectively. The APs lacked the provisions regarding conventional weapons which have been fulfilled by, later on, Conventions on Conventional Weapons in 1980 and its five protocols. The Rome Statute of the Permanent International Criminal Court in 1998 has almost kept a great contribution in the full development of IHL.

Although sufficient international conventions, protocols, optional protocols, statutes and declarations on the LOW are in force in this modern age, they have 
not been signed and ratified by all states of the world like GCs. And most importantly the world communities those ratified the conventions and protocols, even many of them did not enact sufficient state legislation inserting the provisions of Geneva laws and other international documents for proper and effective implementation of IHL. This study makes a convene to all States of the globe to sign and ratify the international instruments of IHL and make necessary domestic laws inserting the provisions of Geneva and other laws of war existing in the world and establish national court or tribunal for trial of IHL violators.

\section{References}

Additional Protocol (AP, I) to the Geneva Conventions of 12 August 1949, and Relating to the Protection of Victims of International Armed Conflicts, 1125 UNTS 3, 8 June 1977 (entered into force 7 December 1978).

Additional Protocol (AP, II) to the Geneva Conventions of 12 August 1949, and Relating to the Protection of Victims of Non-International Armed Conflicts, 1125 UNTS 3, 8 June 1977 (entered into force 7 December 1978).

Additional Protocol (AP, III) to the Geneva Conventions of 12 August 1949, and Relating to the Adoption of an Additional Distinctive Emblem (Protocol III), 8 December 2005. https://ihl-databases.icrc.org/ihl/INTRO/615?OpenDocument

Claude, P., Jean, D. P., Yves, S., Bruno, Z., Philippe, E., Hans, P. G., \& Claude, F. (1987). Commentary on the Additional Protocols of 8 June 1977to the Geneva Conventions of 12 August 1949. International Committee of the Red Cross.

Convention Relative to the Treatment of Prisoners of War (1929). Geneva, 27 July 1929, Treaties and State Parties of Such Treaties, ICRC. http://www.icrc.org/ihl/INTRO/305

Declaration Renouncing the Use, in Time of War, of Certain Explosive Projectiles Saint Petersburg (29 November/11 December 1868).

Draper. G. I. A. D. (1979). The Implementation and Enforcement of the Geneva Conventions of 1949 and the Two Additional Protocols of 1977. 164, The Hague Academy of International Law.

Fleck, D., \& Bothe, M. (1999). The Hand Book of International Humanitarian Law (3rd ed.). Oxford: Oxford University Press.

Geneva Convention (GC, I) for the Amelioration of the Condition of the Wounded and Sick in Armed Forces in the Field of 12 August 1949, 75 UNTS 31 (Entered into Force 21 October 1950).

Geneva Convention (GC, II) for the Amelioration of the Condition of the Wounded and Sick and Shipwrecked Members of Armed Forces at Sea of 12 August 1949, 75 UNTS 31 (Entered into Force 21 October 1950).

Geneva Convention (GC, III) Relative to the Treatment of Prisoners of War of 12 August 1949, 75 UNTS 31 (Entered into Force 21 October 1950).

Geneva Convention (GC, IV) Relative to the Protection of Civilian Persons at Time of War of 12 August 1949, 75 UNTS 31 (Entered into Force 21 October 1950).

Gill, T. \& Fleck, D. (Eds.) The Hand Book of the International Law of Military Operations. Oxford: Oxford University Press.

ICRC (1956). Draft Rules for the Limitation of the Dangers Incurred by the Civilian Population in Time of War. https://ihl-databases.icrc.org/ihl/INTRO/420?OpenDocument

ICRC (2005) The ICRC Since 1945: The Geneva Conventions 1949; Background to the 
Major Revision and Expansion of the Geneva Conventions after World War II; Overview of Some of Their Most Important Innovations. International Committee of the Red Cross and Red Crescent.

http://www.icrc.org/eng/resources/documents/misc/icrc-genevaconventions-revision-1 949.htm

International Crimes Tribunal Act 1973 (as amended in 2009).

James, A. T. (2009). War, Violence and Population: Making the Body Count. New York: The Guilford Press.

Khan, H. K. (2013). Islam and International Humanitarian Law. Paper Presented in $23^{\text {rd }}$ SAT on International Humanitarian Law in Dhaka.

Maresca, L., \& Maslen, S. (2000). The ICRC's Draft Rules to Protect Civilian Populations 1955-1956. In L. Maresca, \& S. Maslen (Eds.), The Banning of Anti-Personnel Landmines. The Legal Contribution of the International Committee of the Red Cross 1955-1999 (pp. 15-18). Cambridge: Cambridge University Press.

http://ebooks.cambridge.org/chapter.jsf?bid=CBO9780511494246\&cid=CBO97805114 $\underline{94246 \mathrm{~A} 012}$

National Implementation of International Humanitarian Law (2010). International Review of the Red Cross. 92(879).

Pictet, J. (1984). Development and Principles of International Humanitarian Law. Leiden: Martinus Nijhoff Publishers.

Rome Statute of International Criminal Court 1998, adopted 17 July 1998, entered into force on 1 July 2002, arts $81 \& 82$.

https://ihl-databases.icrc.org/ihl/INTRO/585?OpenDocument

Sandoz, Y., Swinarski, C., \& Zimmermann, B. (Eds.) (1987). Commentary on the Additional Protocols of 8 June 1977 to the Geneva Conventions of 12 August 1949 (p. xxxi). Geneva: International Committee of the Red Cross, Martinus Nijholf Publications.

Sassòli, M., Bouvier, A. A., \& Quintin, A. (2012). How Does Law Protect in Law, Cases; Documents and Teaching Materials on Contemporary Practice in International $\mathrm{Hu}$ manitarian Law. In Outline of International Humanitarian Law (3rd ed.). International Committee of the Red Cross.

Spoerri, P. (2009). The Geneva Conventions 1949: Origin and Current Significance. ICRC, Resource Centre.

http://www.icrc.org/eng/resources/documents/statement/geneva-conventions-stateme $\underline{\text { nt-120809.htm }}$

Terry, G., \& Fleck, D. (Eds.) (2010). The Hand Book of the International Law of Military Operations. Oxford: Oxford University Press.

The Covenant of the League of Nations (1919). Adopted on 28 June 1919, came into force 16, January 1920 established by Part- 1 of the treaty of Versailles. 